\title{
DEVELOPMENT AND EVALUATION OF A WEIGHABLE LYSIMETER TO DETERMINE CROP EVAPOTRANSPIRATION
}

\author{
C. P. Obioma ${ }^{1}$, K. N. Nwaigwe ${ }^{2}$, C. D. Okereke ${ }^{3}$ \\ Department of Agricultural engineering, Federal University of Technology Owerri, Imo State, Nigeria, P. M. B. 1526 \\ Department of Agricultural engineering, Federal University of Technology Owerri, Imo State, Nigeria, P. M. B. 1526 \\ Department of Agricultural engineering, Federal University of Technology Owerri, Imo State, Nigeria, P. M. B. 1526
}

\begin{abstract}
The development and evaluation of a weighable lysimeter to determine crop evapotranspiration is presented. A weighable lysimeter with a diameter of $31 \mathrm{~cm}$ and a depth of $37 \mathrm{~cm}$ was constructed. The lysimeter was evaluated by using it to estimate the crop evapotranspiration of waterleaf in Umudike in Southeastern Nigeria. The evapotranspiration (ETc) estimates by Pan Evapotranspiration, Blaney - Morin Nigeria, Blaney - Criddle and Modified Hargreaves - Samani methods were compared with the estimation of the weighable lysimeter which provides the most reasonable estimation of ETc and is one of the most reliable methods. The crop was irrigated daily and the daily data generated from the lysimeter were used to calculate the crop evapotranspiration (ETc Lysimeter) between the months of July/ August, 2013. Climatic data obtained for the same period were used to determine the crop evapotranspiration (ETc) using the Pan Evapotranspiration, Blaney - Morin Nigeria, Blaney Criddle and Modified Hargreaves - Samani methods. The total crop evapotranspiration from the Lysimeter between July and August was $141.32 \mathrm{~mm}$, while that of Pan Evapotranspiration (PE), Blaney - Morin Nigeria (BMN), Blaney - Criddle (BC) and Modified Hargreaves - Samani (MHS) were $147.72 \mathrm{~mm}, 136.81 \mathrm{~mm}, 131.61 \mathrm{~mm}$ and $132.52 \mathrm{~mm}$, respectively. Test of hypothesis using z-Test indicates that there was no significant difference between the means of the ET by lysimeter and each of the other methods (Blaney - Criddle, Pan Evapotranspiration, Modified Hargreaves - Samani and Blaney - Morin Nigeria) for a 5\% level of significance as $z$-cal $<z$-critical for the growth period of $15^{\text {th }}$ July to $18^{\text {th }}$ August, 2013.
\end{abstract}

Keywords: Weighable Lysimeter, Evapotranspiration, Waterleaf.

\section{INTRODUCTION}

Weighing lysimeters have a long history of development and different designs have been used. Pruitt and Angus (1960) presented one of the initial reports on lysimetry. Some of the first lysimeters consisted of a big shallow tank (Pruitt and Angus, 1960), small rectangular containers (Van Bavel and Meyers, 1962), or small cylindrical tanks weighed with scales (England, 1963). Subsequent developments led to an increase in lysimeter size which then required the use of weighing mechanism with advanced counterbalance weights (Ritchie and Burnett, 1968; Armijo et al., 1972). Since that time, the majority of lysimeters incorporated balance beam and counterweight mechanism (Malone et al., 1999) that offset the dead weight from the soil and the container. A number of lysimeters using this methodology have been built (Marek et al., 1988; Howel et al., 1998) been the majority devoted to determining the $\mathrm{ET}_{\mathrm{c}}$ of major annual crops, such as alfalfa (Hunsaker et al., 2002), wheat (Dugas et al., 1985) or sorghum (Ritchie and Burnett, 1968). More recently, improvements in the design and installation of lysimeters which are completely supported by load cells and data acquisition systems have enabled the design and installation of lysimeters which are completely supported by load cells without balance beam mechanisms or other moving parts (Allen and Fisher, 1990). The major drawback of the design as compared to mechanic designs is that the entire dead load (soil, container and crop) and live load of the tank are measured. Evapotranspiration is defined as the combination of two distinct processes: the evaporation of the water directly from the ground surface and the perspiration through the plants' stomata (Allen et al., 2006). Accurate evapotranspiration estimates are essential to identify the time variations on irrigation needs, to improve the allocation of water resources, and to evaluate the effect of the use of the land and changes in the management of the water balance (Ortega - Farias et al., 2009).Evapotranspiration can be obtained by direct or estimate measures of climatic elements, using empirical methods. The direct method is represented by several types of lysimeters, being the most accurate method, and considered standard - tool for the determination of evapotranspiration (Bernardo et al., 2006; Amorim, 1998). There are several empirical methods in literature that use meteorological elements data to estimate the evapotranspiration. These methods are based on observations and statistical analysis, and are generally adequate for a specific climatic or region condition (Gravilan et al., 2006).

The objectives of this study are to construct a weighable lysimeter and to evaluate the ET of waterleaf determined from the lysimeter with the ETc estimates by Pan Evapotranspiration, Blaney - Morin Nigeria, Blaney Criddle and Modified Hargreaves - Samani methods in Umudike in Southeastern Nigeria. 


\section{MATERIALS AND METHODS}

\subsection{Study Area}

The study area is National Root Crops Research Institute (NRCRI), Umudike situated on longitude $07^{\circ} 33^{\prime} \mathrm{N}$ and latitude $05^{\circ} 29^{\prime} \mathrm{N}$ at about $8 \mathrm{~km}$ East of the Umuahia-Ikot Ekpene road. It is $140 \mathrm{~km}$ North of Port Harcourt International Airport, $135 \mathrm{~km}$ south of Enugu Airport and $80 \mathrm{~km}$ East of Owerri Airport. The Institute is located in Ikwuano Local Government Area of Abia State. They occupy a total land of 600 hectares. The area is endowed with sandy loam soil (Anon, 1973).

\subsection{Design Consideration}

The weighable lysimeter has a cylindrical shape with a diameter of $31 \mathrm{~cm}$ and a depth of $37 \mathrm{~cm}$. It was designed to have enough depth to accommodate the rooting depth of the vegetable crop. The root depth of a mature waterleaf is between $10 \mathrm{~cm}-12 \mathrm{~cm}$. A drainage discharge and capture system was designed to facilitate drainage from the lysimeter (Shukla et al., 2007).

\subsection{Lysimeter Design}

The lysimeter is cylindrical in shape. The volume of the cylinder is given by;

$$
\mathrm{V}_{\mathrm{L}}=\pi \cdot \mathrm{r}^{2} \cdot \mathrm{h}
$$

Where, $\mathrm{V}_{\mathrm{L}}=$ volume of the lysimeter

$\mathrm{r}=$ radius of cylinder $=\mathrm{d} / 2=31 / 2=15.5 \mathrm{~cm}$

$\mathrm{h}=$ height of the cylinder $=37 \mathrm{~cm}$

$\pi=3.142$

Thus, $\mathrm{V}_{\mathrm{L}}=3.142 \times 15.5^{2} \times 37=27,930.0 \mathrm{~cm}^{3}$

The mass of lysimeter,

$$
\mathrm{M}=\rho . \mathrm{V}
$$

Where $\rho=$ density of material $=0.210 \mathrm{~g} / \mathrm{cm}^{3}$ (Hicks, 1995) $\mathrm{V}=$ volume of lysimeter $=27,930.0 \mathrm{~cm}^{3}$

Thus, $\mathrm{M}=0.210 \times 27,930.0$

$\mathrm{M}=5,865 \mathrm{~g}$

In designing the lysimeter, ease of construction, simple installation, and minimal maintenance requirements and low cost were important considerations.

Table 1: Results of design calculations and parameters

\begin{tabular}{|l|l|}
\hline Parameters/items & Values/specification \\
\hline Volume of lysimeter & $27,930.0 \mathrm{~cm}^{3}$ \\
\hline Mass of lysimeter & $5,865 \mathrm{~g}$ \\
\hline Lysimeter container & $\begin{array}{l}\text { Plastic of } 37 \mathrm{~cm} \mathrm{depth} \text { and } \\
31 \mathrm{~cm} \text { diameter }\end{array}$ \\
\hline Wire mesh & $\begin{array}{l}\text { Stainless wire mesh of size } \\
0.21 \mathrm{~mm}\end{array}$ \\
\hline Plastic pipe & Circular pipe $(0.05 \mathrm{~m}$ dia. $)$ \\
\hline
\end{tabular}

\begin{tabular}{|l|l|}
\hline & and 98cm long \\
\hline Drainage container & plastic container $(10$ liters $)$ \\
\hline Load platform/support & $\begin{array}{l}\text { Length }-54 \mathrm{~cm}, \text { width }- \\
44 \mathrm{~cm} \text { and height of } 69 \mathrm{~cm}\end{array}$ \\
\hline
\end{tabular}

\subsection{Lysimeter Set-Up}

The system is made up of a lysimeter which has a depth of $0.37 \mathrm{~m}(37 \mathrm{~cm})$ and diameter of $0.31 \mathrm{~m}(31 \mathrm{~cm})$. In order to prevent soil particles from causing blockade in the lysimeter through the drainage outlet, a mesh size of $0.21 \mathrm{~mm}$ is placed at the bottom of the lysimeter to act as a filtering mechanism and facilitator of drainage. Then the lysimeter was mounted on a platform and refilled with the soil of the environment. It was irrigated with a known volume of water. The lysimeter was linked at its base with a $0.02 \mathrm{~m}(2 \mathrm{~cm})$ diameter of plastic pipe, with length of $0.98 \mathrm{~m}(98 \mathrm{~cm})$. A 10 liter plastic container was used to collect drained water. Then the lysimeter was allowed to set for 24 hours after irrigation and drainage processes. Before transplanting, the lysimeter was allowed to stop draining from the drainage outlet after saturation. The materials used in this study are a Weighable lysimeter which is the main experimental set up used in the determination of the crop evapotranspiration and an electronic weighing balance used for weighing the lysimeter before and after irrigation.

\subsection{Data Collection}

The irrigation was monitored by measuring out the quantity of water in a calibrated container before application. The lysimeter is drained by gravity and percolated water was collected in the collection container through a drain pipe and was measured in a measuring cylinder. For the computation of evapotranspiration using modified Hargreaves-Samani, Blaney - Morin Nigeria, Blaney - Criddle and Pan Evapotranspiration methods. The weather data collected from the Meteorological station at National Root Crops Research Institute, Umudike include air temperature, sunshine, relative humidity, and solar radiation. 


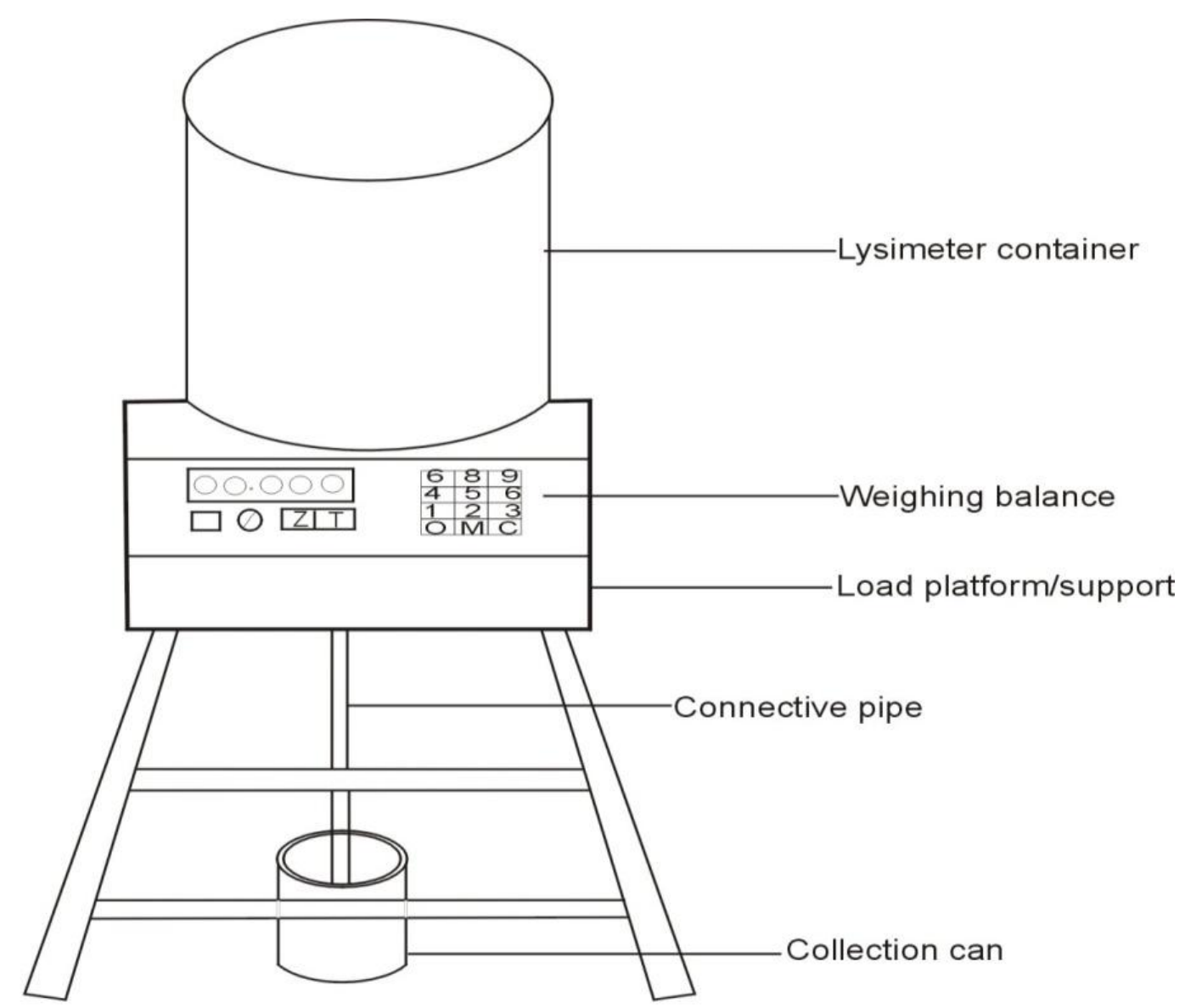

Fig. 3.2: Set-up of the weighable lysimeter 

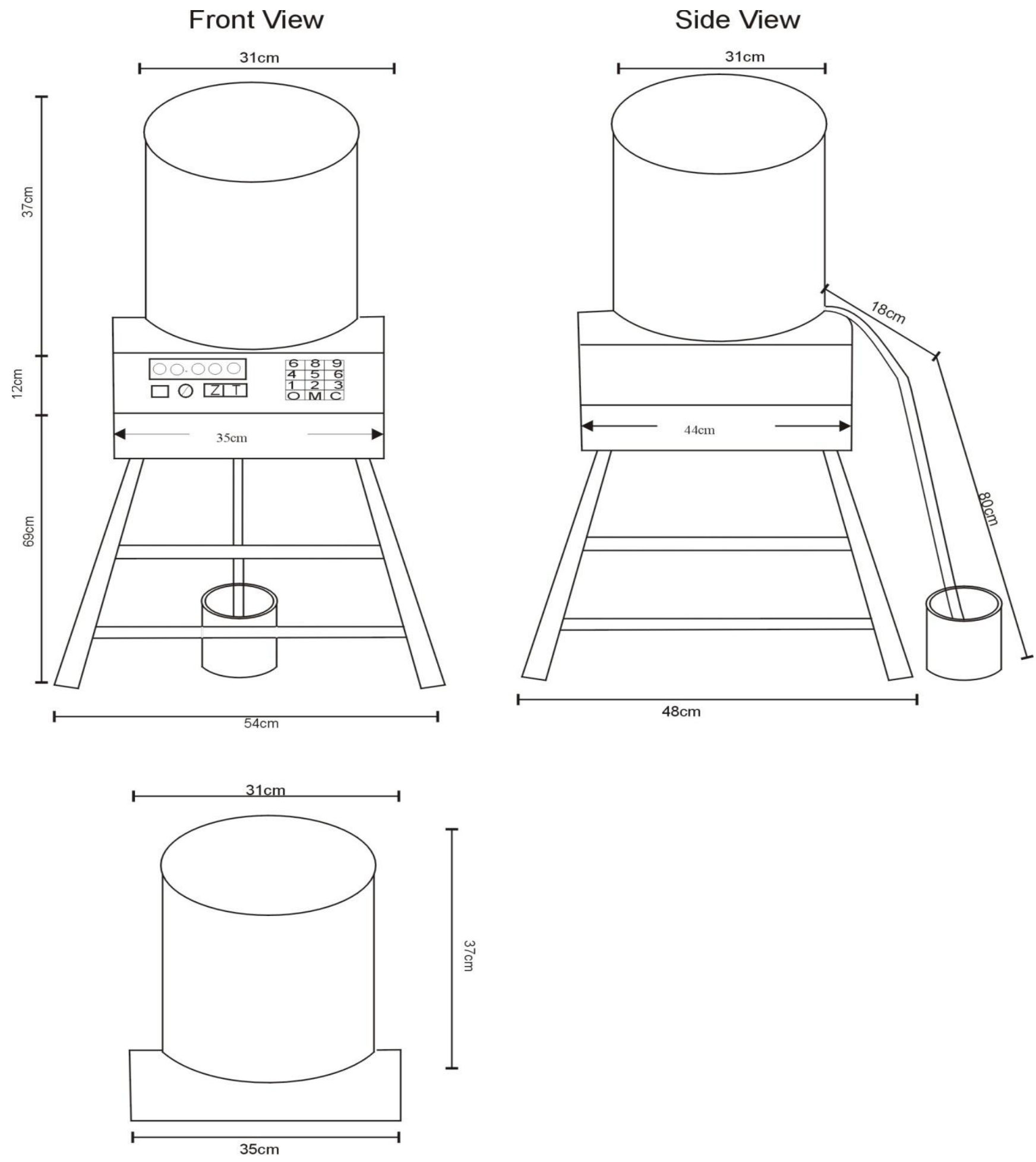

Plan

Fig. 3.3: The design of the weighable lysimeter 


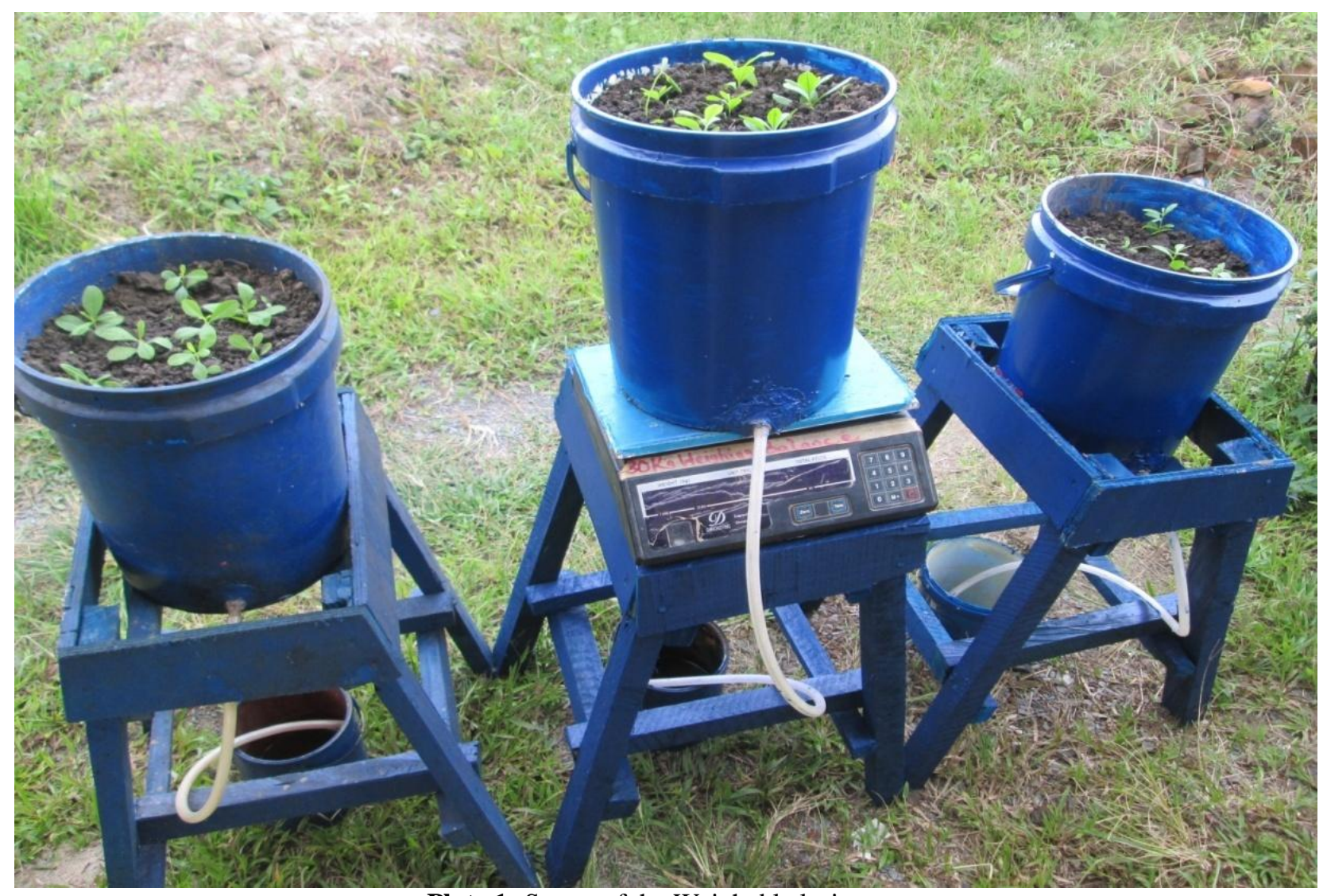

Plate 1: Set-up of the Weighable lysimeter

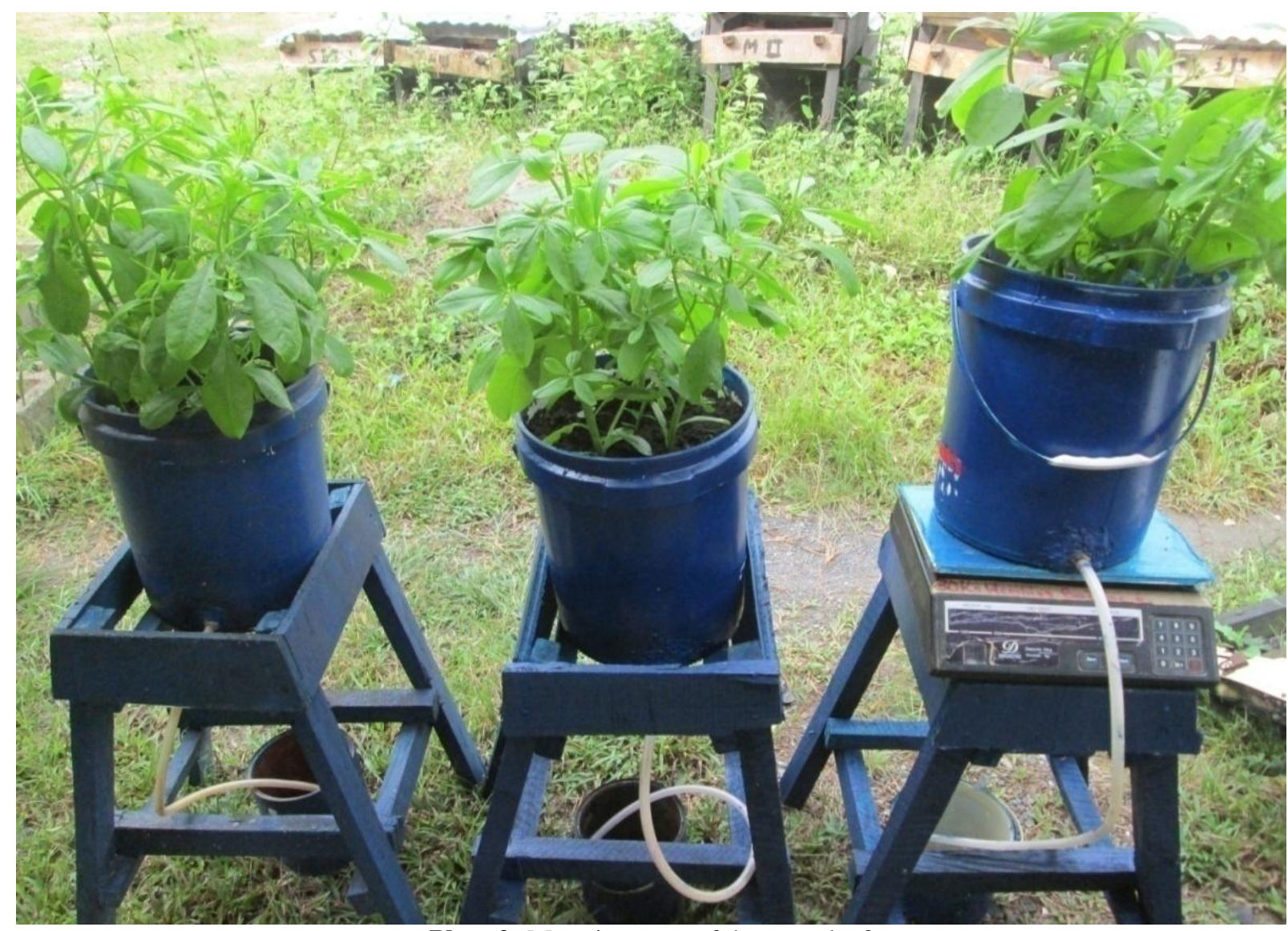

Plate 2: Maturity stage of the waterleaf 


\section{DETERMINATION}

OF

\section{EVAPOTRANSPIRATION (ET)}

\subsection{The Modified Hargreaves-Samani (MHS)} Method

The form of Hargreaves-Samani equation presented in FAO - 56 by Allen et al. (1998) is:

$$
\mathrm{ET}_{\mathrm{o}}=0.0023 \times\left(\mathrm{T}_{\max }-\mathrm{T}_{\min }\right)^{0.5}\left(\mathrm{~T}_{\text {mean }}+17.8\right) \mathrm{R}_{\mathrm{a}}
$$

Where $\mathrm{ET}_{\mathrm{o}}$ is reference evapotranspiration $\left(\mathrm{mm} \mathrm{day}^{-1}\right)$

$\mathrm{T}_{\text {mean }}$ is the daily mean air temperature $\left({ }^{\circ} \mathrm{C}\right)$

$\mathrm{T}_{\max }$ is the daily maximum air temperature $\left({ }^{\circ} \mathrm{C}\right)$

$\mathrm{T}_{\min }$ is the daily minimum air temperature $\left({ }^{\circ} \mathrm{C}\right)$

$R_{a}$ is the extraterrestrial radiation (mm day ${ }^{-1}$ )

The crop coefficient of waterleaf for development and final stage is 1 and 0.95 respectively (FAO, 2000).

\subsection{Blaney - Morin Nigeria (BMN) Model}

The evapotranspiration is computed using the formulas developed by Blaney - Morin Nigeria (Duru, 1984).

$$
\mathrm{ET}=\frac{r_{f}(0.45 t+8)\left(520-R^{1.31}\right)}{100} \quad \ldots \ldots . . \quad 4
$$

Where, ET = evapotranspiration (mm/day)

$\mathrm{r}_{\mathrm{f}}=$ radiation ratio $/$ fraction $=\mathrm{r}_{\text {daily }} / \mathrm{r}_{\max }$

$\mathrm{r}_{\text {daily }}=$ daily radiation

$\mathrm{r}_{\max }=$ maximum monthly radiation, $\mathrm{T}=\operatorname{temperature}\left({ }^{\circ} \mathrm{C}\right)$

$\mathrm{R}=$ daily relative humidity $(\%)$

\subsection{Blaney - Criddle (BC) Method}

The evapotranspiration is calculated by the equation developed by Blaney and Criddle (1950).

$$
\mathrm{ET}_{\mathrm{o}}=\mathrm{p}\left(0.46 \mathrm{~T}_{\text {mean }}+8\right)
$$

Where, $\mathrm{ET}_{\mathrm{o}}=$ reference crop evapotranspiration $(\mathrm{mm} /$ day $)$ $\mathrm{T}_{\text {mean }}=$ mean daily temperature $\left({ }^{\circ} \mathrm{C}\right)$

$\mathrm{P}=$ mean daily percentage of monthly day time hours

\subsection{The Pan Evapotranspiration (PE) Method}

The reference evapotranspiration will also be determined by pan evaporation method using Class A pan. The relationship between the evaporation and the reference evapotranspiration is given as;

$$
\mathrm{ET}_{\mathrm{o}}=\mathrm{K}_{\mathrm{p}} \times \mathrm{E}_{\mathrm{p}}
$$

Where $\mathrm{ET}_{\mathrm{o}}=$ Reference evapotranspiration $\mathrm{K}_{\mathrm{p}}=$ Pan coefficient, $\mathrm{E}_{\mathrm{p}}=$ Pan evaporation

The crop evapotranspiration $\left(\mathrm{ET}_{\mathrm{c}}\right)$ is calculated using the equation
Where $\mathrm{ET}_{\mathrm{c}}=$ Crop evapotranspiration, $\mathrm{ET}_{\mathrm{o}}=$ Reference evapotranspiration

$\mathrm{K}_{\mathrm{c}}=$ Crop coefficient.

The daily evaporation values were multiplied with the pan coefficient (0.8) to get the reference evapotranspiration which was further multiplied with the crop coefficient to get the crop evapotranspiration. For waterleaf, crop coefficient for the development stage or mid stage is 1 , while the late season is 0.95 (FAO, 2000).

\subsection{Data Analysis}

The ET data of the five methods was subjected to $\mathrm{z}$-Test in Excel computer software to determine if there is significant difference between the means of the ET determined by Weighable Lysimeter and each of the other methods (Pan Evapotranspiration (PE), Blaney - Morin Nigeria (BMN), Blaney - Criddle (BC) and Modified Hargreaves - Samani (MHS).

The following hypothesis is tested:

- The Null hypothesis, Ho: $\mu_{1}=\mu_{2}=\ldots \mu_{\mathrm{k}}$ where $\mu$ is the population means, that is, there is no significant difference between evapotranspiration of waterleaf determined by Weighable Lysimeter and each of the other four methods (BMN, BC, PE, MHS).

- The alternative hypothesis, $\mathrm{H} 1: \mu_{1} \neq \mu_{2}=\ldots \mu_{\mathrm{k}}$, that is, there is a significant difference in the evapotranspiration of waterleaf determined by Weighable Lysimeter and each of the other four methods (BMN, BC, PE, MHS).

\section{RESULTS AND DISCUSSION}

\subsection{Results}

Results of evapotranspiration estimated by the five methods is presented in Table 2. The results of comparison of means of the $\mathrm{ET}_{\mathrm{c}}$ by the Lysimeter method with that obtained by each of the other four methods at 5\% level of significance are presented in Table 3, Table 4, Table 5, Table 6. Figure 4.1 show the $\mathrm{ET}_{\mathrm{c}}$ trend after planting the crop (waterleaf) for the five different methods used to determine crop evapotranspiration.

$$
\mathrm{ET}_{\mathrm{c}}=\mathrm{ET}_{\mathrm{o}} \times \mathrm{K}_{\mathrm{c}}
$$




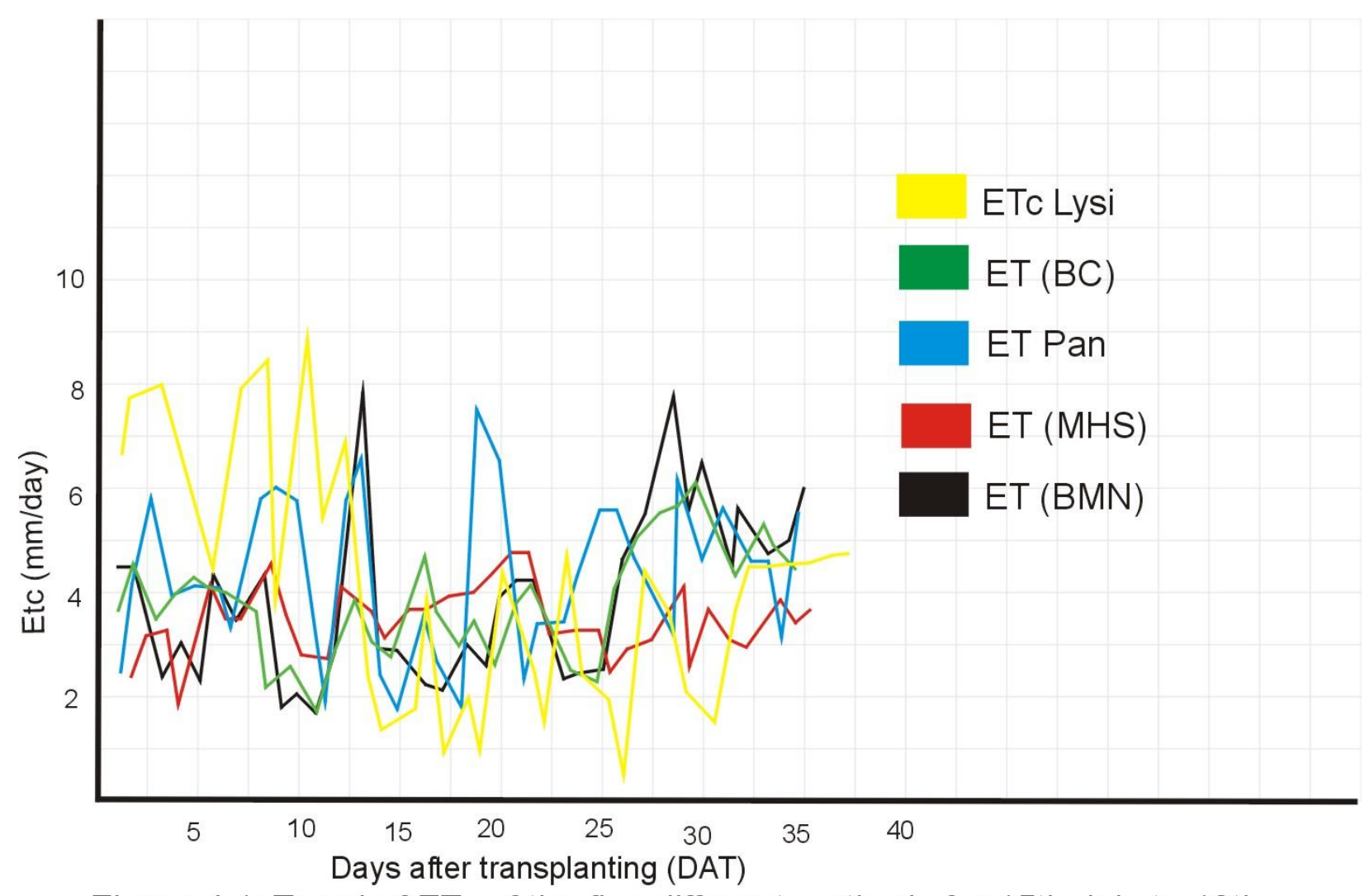

Figure 4.1: Trend of ETc of the five different methods for 15th July to 18th August period.

Table 2: Comparison of results from the five methods $\left(15^{\text {th }} \mathrm{July}-18^{\text {th }}\right.$ August $)$

\begin{tabular}{|c|c|c|c|c|c|}
\hline Days & $\begin{array}{l}\text { ETc lysimeter } \\
\text { (mm/day) }\end{array}$ & $\begin{array}{l}\text { ETc Blaney- } \\
\text { Criddle } \\
(\mathrm{mm} / \text { day })\end{array}$ & $\begin{array}{l}\text { ETc Pan } \\
\text { evaporation } \\
\text { (mm/day) }\end{array}$ & $\begin{array}{l}\text { ETc Hargrea } \\
\text {-ves Samani } \\
(\mathrm{mm} / \text { day })\end{array}$ & $\begin{array}{l}\text { ETc Blaney- } \\
\text { Morin Nigeria } \\
(\mathrm{mm} / \text { day) }\end{array}$ \\
\hline 1 & 6.75 & 3.72 & 2.40 & 3.42 & 4.61 \\
\hline 2 & 7.76 & 4.41 & 4.00 & 3.14 & 4.61 \\
\hline 3 & 8.00 & 3.47 & 5.60 & 4.24 & 2.42 \\
\hline 4 & 4.43 & 3.85 & 3.70 & 3.78 & 3.21 \\
\hline 5 & 7.90 & 4.16 & 4.00 & 4.00 & 2.26 \\
\hline 6 & 8.74 & 4.00 & 4.00 & 3.27 & 4.46 \\
\hline 7 & 3.86 & 3.86 & 3.20 & 3.41 & 3.37 \\
\hline 8 & 8.90 & 3.74 & 5.60 & 4.58 & 4.49 \\
\hline 9 & 5.38 & 2.14 & 5.84 & 3.36 & 1.74 \\
\hline 10 & 6.96 & 2.32 & 5.60 & 4.24 & 2.14 \\
\hline 11 & 2.32 & 1.55 & 1.84 & 3.67 & 1.62 \\
\hline 12 & 1.38 & 2.61 & 5.60 & 4.10 & 2.88 \\
\hline 13 & 1.66 & 3.52 & 6.40 & 3.54 & 7.78 \\
\hline 14 & 3.84 & 3.04 & 2.40 & 3.07 & 2.98 \\
\hline 15 & 0.96 & 2.82 & 1.60 & 4.51 & 2.94 \\
\hline 16 & 1.92 & 4.48 & 3.30 & 3.50 & 2.44 \\
\hline 17 & 0.96 & 3.50 & 2.56 & 3.65 & 2.16 \\
\hline 18 & 4.32 & 2.93 & 1.60 & 3.78 & 3.03 \\
\hline 19 & 2.30 & 3.31 & 7.20 & 4.16 & 2.82 \\
\hline 20 & 1.84 & 2.63 & 6.40 & 4.48 & 3.94 \\
\hline 21 & 4.66 & 3.78 & 2.40 & 4.36 & 4.34 \\
\hline 22 & 2.56 & 4.06 & 3.20 & 3.07 & 4.31 \\
\hline 23 & 2.00 & 2.90 & 3.20 & 4.09 & 2.28 \\
\hline 24 & 0.54 & 2.62 & 4.16 & 4.15 & 2.39 \\
\hline 25 & 4.38 & 2.20 & 5.32 & 3.49 & 2.62 \\
\hline
\end{tabular}




\begin{tabular}{|l|l|l|l|l|l|}
\hline 26 & 3.68 & 4.13 & 5.32 & 3.05 & 4.67 \\
\hline 27 & 2.24 & 4.87 & 4.56 & 3.44 & 5.45 \\
\hline 28 & 1.42 & 5.28 & 3.04 & 3.96 & 7.55 \\
\hline 29 & 3.40 & 5.53 & 6.08 & 3.40 & 5.44 \\
\hline 30 & 4.20 & 5.97 & 4.56 & 3.59 & 6.40 \\
\hline 31 & 4.34 & 4.91 & 5.32 & 3.14 & 4.50 \\
\hline 32 & 4.30 & 4.50 & 4.56 & 3.76 & 5.36 \\
\hline 33 & 4.35 & 5.22 & 4.56 & 3.84 & 4.82 \\
\hline 34 & 4.43 & 4.94 & 3.04 & 4.34 & 5.02 \\
\hline 35 & 4.64 & 4.64 & 4.56 & 4.58 & 6.12 \\
\hline Total & 141.32 & 131.61 & 146.72 & 132.52 & 136.81 \\
\hline Mean & 4.04 & 3.76 & 4.19 & 3.79 & 3.91 \\
\hline
\end{tabular}

Table 3: Summary of z-Test for comparing $\mathrm{ET}_{\mathrm{c}}$ by Lysimeter and Blaney -

\begin{tabular}{|c|c|c|}
\hline z-Test: & & \\
\hline & $\begin{array}{l}E T_{\mathrm{C}} \text { LYSIMETER } \\
(\mathrm{mm} / \text { day) }\end{array}$ & $\begin{array}{l}E T_{C} B C \\
(\mathrm{~mm} / d a y)\end{array}$ \\
\hline Mean & 4.037714286 & 3.760285714 \\
\hline Known Variance & 5.46083 & 1.126203 \\
\hline Observations & 35 & 35 \\
\hline $\begin{array}{ll}\text { Level of significance } & 5 \% \\
\text { Hypothesized Mean Difference } & \\
\end{array}$ & 0 & \\
\hline Z-cal & 0.639499616 & \\
\hline $\mathrm{P}(\mathrm{Z} \leq \mathrm{z})$ two-tail & 0.522497963 & \\
\hline z Critical two-tail & 1.959963985 & \\
\hline
\end{tabular}

Inference: mean $\mathrm{ET}_{\mathrm{c}}$ of waterleaf by Lysimeter method $\left(\mu_{1}\right)$ is same as that obtained by Blaney - Criddle method ( $\left.\mu_{\mathrm{BC}}\right)$ that is, $\mu_{1}$ $=\mu_{\mathrm{BC}}$

Table 4: Summary of z-Test for comparing ETc by Lysimeter and Pan for $15^{\text {th }}$ July $-18^{\text {th }}$ August period

Evapotranspiration (PE) methods

\begin{tabular}{|l|l|l|}
\hline z-Test: & & \\
\hline & & \\
\hline & $\begin{array}{l}\text { ET } \text { LYSIMETER } \\
(\mathrm{mm} / \text { day })\end{array}$ & $\begin{array}{l}E T_{C} P E \\
(\mathrm{~mm} / \text { day })\end{array}$ \\
\hline Mean & 4.037714286 & 4.192 \\
\hline Known Variance & 5.46083 & 2.221322 \\
\hline Observations $5 \%$ & 35 & 35 \\
\hline $\begin{array}{l}\text { Level of significance Mean Difference } \\
\text { Hypothesized M-cal }\end{array}$ & 0 & \\
\hline P(Z z) two-tail & -0.329320139 & \\
\hline z Critical two-tail & 0.741913724 & \\
\hline
\end{tabular}

Inference: mean $\mathrm{ET}_{\mathrm{c}}$ of waterleaf by Lysimeter method $\left(\mu_{1}\right)$ is same as that obtained by Pan Evapotranspiration method $\left(\mu_{\mathrm{PE}}\right)$ that is, $\mu_{1}=\mu_{\mathrm{PE}}$

Table 5: Summary of z-Test for comparing ETc by Lysimeter and Modified Hargreaves - Samani (MHS) methods for $15^{\text {th }}$ July $18^{\text {th }}$ August period

\begin{tabular}{|l|l|l|}
\hline z-Test: & & \\
\hline & & $\begin{array}{l}E T_{c} M H S \\
(\mathrm{~mm} / \text { day })\end{array}$ \\
\hline
\end{tabular}




\begin{tabular}{|l|l|l|}
\hline Mean & 4.037714286 & 3.776 \\
\hline Known Variance & 5.4608299 & 0.2220188 \\
\hline Observations & 35 & 35 \\
\hline $\begin{array}{l}\text { Level of significance } \\
\text { Hypothesized Mean Difference }\end{array}$ & 0 & \\
\hline z-cal & 0.649498877 & \\
\hline $\mathrm{P}(\mathrm{Z} \leq \mathrm{z})$ two-tail & 0.516015972 & \\
\hline $\mathrm{z}$ Critical two-tail & 1.959963985 & \\
\hline
\end{tabular}

Inference: mean $\mathrm{ET}_{\mathrm{c}}$ of waterleaf by Lysimeter method $\left(\mu_{1}\right)$ is same as that obtained by Modified Hargreaves - Samani method $\left(\mu_{\mathrm{MHS}}\right)$ that is, $\mu_{1}=\mu_{\mathrm{MHS}}$

Table 6: Summary of z-Test for comparing ETc Lysimeter and Blaney - Morin Nigeria (BMN) methods for $15^{\text {th }}$ July $-18^{\text {th }}$ August periods

\begin{tabular}{|l|l|l|}
\hline z-Test: & $\begin{array}{l}\text { ET } \text { LYSIMETER } \\
(\text { mm/day })\end{array}$ & $\begin{array}{l}E T_{C} \text { BMN } \\
(\mathrm{mm} / \text { day })\end{array}$ \\
\hline Mean & 4.037714286 & 3.919142857 \\
\hline Known Variance & 5.46083 & 2.546102 \\
\hline Observations & 35 & 35 \\
\hline $\begin{array}{l}\text { Level of significance } \\
\text { Hypothesized Mean Difference }\end{array}$ & 0 & \\
\hline z-cal & 0 & \\
\hline $\mathrm{P}(\mathrm{Z} \leq \mathrm{z})$ two-tail & 0.247902556 & \\
\hline $\mathrm{z}$ Critical two-tail & 0.804209802 & \\
\hline
\end{tabular}

Inference: mean $\mathrm{ET}_{\mathrm{c}}$ of waterleaf by Lysimeter method $\left(\mu_{1}\right)$ is same as that obtained by Blaney - Morin Nigeria method $\left(\mu_{\mathrm{BMN}}\right)$ that is, $\mu_{1}=\mu_{\mathrm{BMN}}$

\subsection{Discussion}

In Figure 4.1, the waterleaf crop evapotranspiration of the different methods follow similar trend and it increases slightly at the beginning of the crop growing period and gradually decreases at the ending of the growing period of $15^{\text {th }}$ July to $18^{\text {th }}$ August, 2013. From Table 2, the evapotranspiration of waterleaf determined by Lysimeter, Pan Evapotranspiration (PE), Blaney - Morin Nigeria $(\mathrm{BMN})$, Blaney - Criddle (BC) and Modified Hargreaves Samani (MHS) methods from $15^{\text {th }}$ July to $18^{\text {th }}$ August, 2013 were $141.32 \mathrm{~mm}, 147.72 \mathrm{~mm}, 136.81 \mathrm{~mm}, 131.61 \mathrm{~mm}$ and $132.52 \mathrm{~mm}$, respectively. The values though differ in magnitude by between $4.5 \%$ to $6.9 \%$, the result of $z$ - Test for comparison of mean evapotranspiration data for the period showed that there is no significant difference between crop evapotranspiration determined by lysimeter method and the other four methods for a $5 \%$ level of significant as z-cal < z- critical. Since Lysimeter is the most widely accepted direct method, the Pan Evapotranspiration, Blaney - Morin Nigeria, Blaney - Criddle and Modified Hargreaves - Samani methods can be said to be efficient in the estimation of the crop evapotranspiration of waterleaf in Umudike, Southeast Nigeria. Performance of five simple ET methods was tested in this study with the aim to guide the researchers and water practitioners in selecting appropriate methods for estimating ET of waterleaf in the study area. To measure the accuracy and reliability of the ET methods. ET estimates by each method were compared with the estimation of the Weighable Lysimeter. Though the capability of these methods are almost similar, Pan evapotranspiration method followed by Blaney - Criddle method needs less number of parameters to estimate ET compared to Modified Hargreaves - Samani method and Blaney - Morin Nigeria method, and therefore much easier to use and economical.

There was no definite pattern for the daily crop ET with respect to crop growth as the values kept rising and falling throughout the crop growing season. This is typical of daily ETc during the growth seasons as higher ET does happen on very sunny day and cloudless days. However, the pattern of crop ET with respect to crop growth was better observed considering the daily average crop ET.

\section{CONCLUSION}

The values of ETc determined from the Pan Evapotranspiration, Blaney - Morin Nigeria, Blaney Criddle and Modified Hargreaves - Samani methods were validated by the Weighable lysimeter method. The study revealed that the crop evapotranspiration of waterleaf (Talinum triangulare) in Umudike, Southeast Nigeria between the month of July and August from Weighable lysimeter, Pan Evapotranspiration, Blaney - Morin Nigeria, Blaney - Criddle and Modified Hargreaves - Samani methods were $141.32 \mathrm{~mm}, 147.72 \mathrm{~mm}, 136.81 \mathrm{~mm}, 131.61$ $\mathrm{mm}$ and $132.52 \mathrm{~mm}$, respectively. From the above analysis, it can be concluded that there was no significant difference between the means of the ET lysimeter and each of the other 
methods (Blaney - Criddle, Pan Evapotranspiration, Modified Hargreaves - Samani and Blaney - Morin Nigeria) as $\mathrm{z}$-cal $<\mathrm{z}$-critical for a $5 \%$ level of significance for the growth period of $15^{\text {th }}$ July to $18^{\text {th }}$ August, 2013. From the above analysis, it can be concluded that the five ET methods are suitable for estimating ET of waterleaf (Talinum triangulare) in the study area.

\section{REFERENCES}

[1] Allen, R.G. and Fisher, D.K. (1990). Low-cost electronic weighing lysimeters. T ASAE 33(6): 1823-1833.

[2] Allen, R.G., Pereira, L.S., Raes, D., Smith, M. (1998). Crop evapotranspiration. Guidelines for computing crop water requirements. FAO Irrigation and Drainage paper 56, Food and Agriculture Organization of United Nations. Rome, Italy.

[3] Allen, R.G., Pruitt, W.O., Wright, J.L., Howell, T.A., Ventura, F., Snyder, R., Itenfisu, D., Steduto, P., Berengena, J., Yrisarry, J.B., Smith, M., Pereira, L.S., Raes, D., Perrier, A., Alves, A., Walter, I., and Elliot, R. (2006). "A recommendation on standardized surface resistance for hourly calculation of reference ET by the FAO 56 Penman-Monteith method." Agricultural Water Management, 81(1-2): 1- 22.

[4] Amorim, M.C. (1998). Evaluating the effectiveness of lysimeter water table constant tank Class "a" and the model penman-monteith (FAO) to reference evapotranspiration (ETo). Master's thesis. Federal University of Lust, Lust. $56 \mathrm{p}$

[5] ANON (1973). Guide to Umudike Agricultural Research and Training Station, Umuahia, Nigeria. Federal Agricultural Research and Training Station, Umudike Press. 40 pp.

[6] Armijo J.D, Twitchell G.A, Burman R.D, Nunn J.R. (1972). A large, undisturbed, weighing lysimeter for grassland studies.T ASAE 15(5): 827-830.

[7] Bernardo, S., Soares, A.A., Mantovani, E.C. (2006). Irrigation manual. 8. ed. Federal University of Vicosa, p 625.

[8] Blaney, H.F. and W.D. Criddle (1950).Determining water requirements in irrigated areas from climatological and irrigation data. USDA/SCS, SCSTP 96.

[9] Dugas W.A., Upchurch D.R., Ritchie J.T. 1985. A weighing lysimeter for evapotranspiration and root measurements. Agron J 77: 821-825.

[10] Duru, J.O. (1984). Blaney - Morin - Nigeria Evapotranspiration Model. Journal of Hydrology, 70: 71-83.

[11] England, C.B. 1963. Water use by several crops in a weighing lysimeter. Agron J 55(3): 239-242.

[12] FAO, 2000. Crop evapotranspiration - Guidelines for computing crop water requirements, By: R. Allen, L. Pereira, D. Raes, M. Smith, Irrigation and drainage paper 56.

[13] Gavilán, P., Lorite, I.J., Tornero, S., Berengena, J. (2006). Regional calibration of Hargreaves equation for estimating reference ET in a semiarid environment. Agriculture Water Management. Management, v. 81: 257-281.

[14] Hicks, T.G. (1995). Standard handbook of Engineering calculation, $3^{\text {rd }}$ edition.

[15] Howell, T.A., Tolk, J.A., Schneider, D., Evett, S.R. 1998. Evapotranspiration, yield, and water use efficiency of corn hybrids differing in maturity. Agron J 90: 3-9.

[16] Hunsaker, D.J., Pinter, P.J., Cai, H. 2002. Alfalfa basal crop coefficients for FAO-56 procedures in the desert regions of the southwestern U.S. T ASAE 45(6): 1799- 1815.

[17] Malone, R.W., Stewardson, D.J., Bonta, J.V., Nelsen, T. 1999.Calibration and quality control of the Coshocton weighing lysimeters. T ASAE 42(3): 701712.

[18] Marek, T.H., Schneider, A.D., Howell, T.A., Ebeling, L.L. 1988.Design and construction of large weighing monolithic lysimeters. T ASAE 31(2): 477-484.

[19] Ortega-Farias, S., Irmak, S., Cuenca, R.H.(2009). Special issue on evapotranspiration measurement and modeling, Irrigation Science v. 28 (1): 1-3.

[20] Pruitt, W.O., Angus, D.E. 1960. Large weighing lysimeter for measuring evapotranspiration. T ASAE 3: 13-15, 18.

[21] Ritchie, J.T., Burnett, E. 1968. A precision weighing lysimeter for row crop water use studies. Agron J 60: 545-549.

[22] Shukla, J., Fouad, J., Saurabh, S., James K. (2007). Water use and crop coefficient for water meter in southwest Florida. Southwest Florida Research and Education Center, Immokalee. Final Report No. WRP-LY-009. Institute of Food and Agricultural sciences (IFAS) University of Florida FL34142.

[23] Van Bavel, C.H.M. and L.E. Meyers. 1962. An automatic weighing lysimeter. Agr. Eng. 43:580-588. 